\title{
Value of foreign experience for the countries with emerging democracies
}

\author{
Akilov Alim Rakhimovich, \\ Doctor of Law, Professor of the Academy of Ministry of Internal \\ Affairs of the Republic of Uzbekistan, \\ Alimov Bobur Alimjanovich, \\ independent competitor, magistr of Law
}

dol http://dx.doi.org/10.26739/2573-5616-2017-7-7-1

\begin{abstract}
: this article reveals the role of foreign experience for the newly independent states that have set themselves the achievement of basic goals of the developed countries of the West: the building of democracy, the constitutional state and the formation of the foundations of civil society. Specific examples show how in the emerging democracies some mistakes were made during the reform of the domestic judicial and legal system. In particular, what went wrong with "Habeas Corpus Act", how can Western standards of justice be useful for modernizing the criminal process in the republics of the former Soviet Union.

In conclusion, it is concluded that the introduction of democracy, other universal values, developed in developed democratic countries, into the daily life of young states will allow the early adoption of these countries into a single fold of the democratic community. And this is the most effective way to eradicate such global threats to mankind as the existence of authoritarian and totalitarian regimes, poverty of the people, corruption and dictatorship of power, crime, terrorism and religious extremism.
\end{abstract}

Keywords: democracy, the international community, the judicial sphere, "habeas corpus", the criminal proceedings, justice, administrative justice.

90-ies of the XX century is marked by a radical change in the political map of the world, which resulted in the collapse of the socialist countries coalition. As a result, new independent states began to appear, the vast 
majority of which, both in words and in actions, began to achieve democracy in all spheres of life, and some - build a constitutional state and form the basis of civil society. At the same time, at the initial stages of the independent development path in these countries, countries with emerging democracies (CED) began to observe dangerous trends in the actions of political triumph, claiming "their own way (model) for building democracy," "the need to take into account local characteristics, the mentality of the people when they reach Democracy ", about the socalled Eastern democracy. Thankfully, such conformist, and populist statements have stopped almost everywhere, under the pressure of world leaders, leaders of such authoritative international organizations as the $\mathrm{UN}$, the OSCE, and the expert advisers of the heads of the CED. Everyone has finally realized that the concepts of "democracy" and other European values are same for everyone.

This fact testifies to the role and influence of the international community in cases where CED makes mistakes in building the government and community. Moreover, some errors are allowed by CED on the "fault" of the international community itself, its prominent representatives or scientists, which are recommended to them as the most prominent experts and experts in this or that field.

In this regard, I will give one very typical example, which took place in the judicial and legal sphere. At the very beginning of the independent development path, the political leadership and domestic specialists of the CED were persistently recommended by many foreign experts to introduce the Habeas Corpus Act into the criminal process as one of the elements of democracy in criminal justice and a reliable tool for protecting human rights, freedom and legitimate interests of citizens. These recommendations were heard at numerous international and domestic forums organized by the international organizations themselves and by the CED itself, as well as numerous publications (articles, abstracts, etc.) that were distributed free of charge in the distribution literature and printed in various foreign and domestic sources. In these recommendations, the essence and meaning of the habeas corpus act as an effective human rights mechanism at the stage of detention and arrest (an analog of detention - measures of procedural coercion used in many post-Soviet republics) was very correctly and thoroughly revealed, but there was one serious gap that reflected negatively in the practice of some countries - the republics of the former USSR.The fact is that in the description of the habeas corpus act procedure 
in the criminal process, it has always been said and written that this institution is used by the court. Brief and clear. As a result, in many postSoviet countries (Russia, Kazakhstan, Uzbekistan, etc.) this was understood as such, namely, that the habeas corpus act is applied by the criminal courts. In this regard, in these countries, they transferred the right to give the sanction for detention from prosecutors to the judges in criminal cases. Thus, a dangerous precedent was created when the same criminal court judge initially authorized the detention of a person, and then considered a criminal case against that person on the merits. This has undermined the justice - its impartiality, violated its fundamental principles, such as objectivity and disinterest of the court. Basically, the bandage was removed from the face of the symbol of justice - the Greek goddess Themis and the analogous Roman goddess of Justice

Moreover, a misunderstanding of the meaning of the habeas corpus act (not only for the above mentioned reason, but also for other reasons) has led to the fact that in these countries the courts have begun to consider and are now considering the illegality of the arrests already made (as is considered in the habeas corpus act), and they themselves sanctioned this type of preventive punishment, thus acquiring the features of a punitive body; secondly, they left the "habeas corpus act" detention out of sight.

Thus, such practice has already been used in some post-Soviet republics for more than a decade, however, strangely enough, neither at the official level nor in informal communication by foreign experts, there has not been a single objection of this wrong, destructive for judges, prosecuting practice. One gets the impression that foreign experts initially set themselves the task to deprive prosecutors of the right to sanction arrests by any means and ways, and having achieved that, they calmed down and did not even look into the essence of the implemented habeas corpus act, introduced by their persistent recommendations. In this regard, I would like to note that international experts (who insistently demanded the right to seize the right of arrest from prosecutors and transfer this right to the courts) are not confused by the fact that in many developed foreign countries (which all these foreign experts represent) citizen arrests are conducted, with the police, by prosecutors.

This is not the only example of the misapplication by CED of norms of international law, the experience of developed democracies in domestic law enforcement practice and national legislation that occurs with the "silent consent" of foreign experts and specialists 
For half a century institution of administrative justice is preserved, that has remained as an inheritance from the USSR in some post-Soviet republics (which includes administrative offenses, and their administrative bodies and courts), the legislative and organizational and legal foundations of which are constantly "improved" and "developed" with Taking into account the legislative and law enforcement practices of developed democracies. On some of such innovations, the authors even receive positive feedback from the western "experts". And none of them will say that their administrative justice and administrative justice of developed democratic countries are two completely different institutions.

If in foreign democratic countries the subject of administrative justice is the violation of the administration order (hence the name), then in the post-Soviet republics - petty crimes, misdemeanors such as petty hooliganism, insult, slander, light bodily injury, etc. If in the western administrative justice only administrative justice officials can be brought to administrative responsibility (hence the name), then in the post-Soviet republics to justice involved mainly citizens. If in foreign countries administrative cases are dealt with independently by a separate system of administrative justice (courts, commissions, etc.) with specially trained judges, then in the republics of the former Union - criminal courts, which are not trained in the specifics of dealing with cases in this category (order, procedure, forms and methods of administration, the vast legal and intra regulatory framework on this subject).

And, most importantly, in these countries there has been no recognition that administrative justice is the only effective institution invented by civilization for protection of ordinary citizens from lawlessness of power, officials, administration. And western legal experts keep a steady silence on this issue, as if nothing terrible is happening, as if the existence of administrative justice is not an indispensable condition for recognizing democracy in a particular country

Finally, there is an impression that none of the "prominent" foreign experts and international consultants who are on abusiness trip to the post-Soviet republics are concerned about the absence of juvenile justice in many post-Soviet republics - an independent system of state bodies and non-governmental organizations, specifically trained in the prevention, investigation, trial and penitentiary correction of misconduct and offenses, committed by minors. 
They do not see anything wrong with the fact that the same body is engaged in both capturing criminals and investigating their crimes and re-educating criminals in the colonies (internal affairs bodies), while the other body itself initiates criminal cases, does the investigation itself. While overseeing itself, supports the prosecution in court (prosecutor's office).

Can't find anything about all these facts in any foreign publication, nothing is mentioned by western experts and international experts, whose opinion is treasured by CED. Too bad. After all, to live in a single international democratic community, to which all countries, without exception, aspire, means, including mutual assistance, the assistance of the developed countries of the CED in the correct and timely introduction of democratic institutions and the eradication of negative, anti-human (and not all, indiscriminately ) inheritance the totalitarian period.

The quick introduction of democracy, and other universal values, developed in the developed democratic countries, into the daily life of young states will allow the speedy adoption of these countries into a single fold of the democratic community. And this is the most effective way to eradicate such global threats to mankind as the existence of authoritarian and totalitarian regimes, poverty, corruption and dictatorship of power, crime, terrorism and religious extremism. 